\title{
"Tari Batik Sekar Galuh" Upaya Pemberdayaan Masyarakat Paseban melalui Aktivitas Seni Budaya Lokal
}

Oleh

Een Herdiani

Jurusan Tari, Sekolah Tinggi Seni Indonesia (STSI) Bandung

Jalan Buahbatu No.212 Bandung

\begin{abstract}
Paseban society is one of traditional Sundanese communities which having uniqueness in their cultural life. The mutual aid behaviour still looks strongly developed based on the faith and wisdom inherent in the community. There is, however, a view that Paseban society has different beliefs from other communities which often creates veiled conflict. Nevertheless, Paseban society has special uniqueness that is Seren Taun activities which presenting the cultural diversity that can unite different religions and beliefs. In the presented diversity, there is an art activity which is often forgotten, namely batik art creation, whereas batik has a high potential to be developed as a promising local asset.
\end{abstract}

Key words: Tari Batik, empowerment, Paseban society

\begin{abstract}
ABSTRAK
Masyarakat Paseban merupakan salah satu kelompok masyarakat adat Sunda yang memiliki keunikan dalam kehidupan budayanya. Sifat gotong royong masih tampak kokoh terbangun dengan berdasarkan keyakinan dan kearifan lokal yang melekat di antara komunitasnya. Namun demikian, ada pandangan bahwa masyarakat Paseban mempunyai keyakinan yang berbeda dari masyarakat umum sehingga kerap menimbulkan konflik terselubung. Kendatipun demikian ada keunikan khusus dalam masyarakatnya yaitu adanya kegiatan Seren Taun dengan menyuguhkan keberagaman budaya yang dapat mempersatukan berbagai agama dan keyakinan. Dari keberagaman budaya yang disajikan, terdapat satu kegiatan seni yang kerap terlupakan yaitu seni membatik, padahal batik memiliki potensi tinggi untuk dikembangkan menjadi aset daerah yang menjanjikan.
\end{abstract}

Kata Kunci: Tari Batik, pemberdayaan, masyarakat Paseban

\section{PENDAHULUAN}

Keragaman budaya dan plularitas kehidupan beragama di beberapa daerah kerap berujung pada disharmoni sosial. Pasalnya berawal dari standarisasi nilai yang dijadikan isntrumen untuk mengukur nilai agama dan kepercayaan lain (di luar keyakinan yang dianutnya) menggunakan standar tunggal, yaitu nilai-nilai yang diperjuangkan dan diyakini oleh kaum mayoritas. Dampaknya terhadap 
kaum minoritas adalah proteksi yang tidak arif. Jika terjadi perbedaan, maka di situlah awal dari perpecahan. Mereka (kaum mayoritas) tidak lagi mengakui eksistensi penganut keyakinan yang berbeda itu. Bahkan manusianya pun seolah-olah dianggap makhluk aneh yang begitu gampang diusir, dibubarkan, bahkan tidak sedikit berujung pada kekerasan fisik. Tidak bias dihindari dari kenyataan bahwa Indonesia adalah negara yang plularis, oleh karenanya plularitas kehidupan beragama mestinya menjadi ajang pembelajaran untuk menemukan kebenaran transendental yang hakiki, bukan mencari perbedaan yang bermuara pada konflik. Sebagai warga negara yang baik di alam demokratis mesti memiliki kesadaran dalam bersosial dan memahami fasilitas sosial. Kesadaran social akan berimplikasi pada integrasi berbangsa dan bernegara, sedangkan pemahaman fasilitas sosial akan mewujudkan bentuk interaksi sosial yang harmonis. Seiring dengan perubahan yang terjadi dalam dunia sosial, instrumen yang digunakan dalam proses interaksi mengalami perubahan pula. Secara teknis komunikasi lebih praktis dan efektif, namun secara humanis tidak ada lagi jalinan harmonis antar warga dalam berinteraksi. Karena kurangnya aktivitas yang dilakukan bersama dan mengusung tujuan bersama. Hal ini sehubungan dengan kurangnya instrumen yang netral dan mampu merekatkan kembali keretakan-keretakan yang terjadi dalam realitas interaksi sosial. Kegiatan yang paling cocok untuk memberikan solusi terhadap masalah ini adalah aktivitas seni budaya lokal.Di samping sifatnya yang komunal, seni budaya lokal sangat mengutamakan kebersamaan.

Seni sebagai salah satu unsur kebudayaan dapat menjadi pemersatu ma- syarakat. Sudah sejak lama bahwa di Jawa Barat, aktivitas seni budaya pada masyarakat Adat seolah menjadi satu kewajiban, sehingga rutin dilaksanakan setiap tahunnya. Hal ini disebabkan oleh tingginya keyakinan masyarakat akan nilai-nilai seni budaya yang terkandung di dalamnya. Upacara-upacara kesuburan masih digelar sebagai ungkapan rasa syukur dan pengharapan hasil pertanian yang melimpah ruah. Kesenian yang digelar dalam berbagai upacara ini hadir dalam berbagai bentuk serta ungkapan rasa yang khas setiap daerahnya. Aktivitas dan bentuk kesenian yang dihadirkan selalu berkaitan dengan konfigurasi sosial yang dipolakan secara kultural sesuai dengan kebudayaan dan adat istiadatnya. Hal ini dapat diartikan sesuai dengan budaya lokal yang berlaku.

Dalam memahami budaya dalam hal ini seni lokal diperlukan pemahaman terhadap corak setiap tradisi dalam masyarakat yang plural. Dalam masyarakat kita perlu ditanamkan keyakinan bahwa kearifan budaya lokal yang berkembang dimasyarakat adalah ajaran yang baik. Seringkali orang beranggapan bahwa budaya dan atau seni lokal tidak sesuai dengan tuntutan zaman, sehingga banyak terjadi kasus seni lokal itu hilang ditelan zaman. Padahal, setiap budaya dan atau seni lokal memiliki fungsi yang dapat dipahami. Seperti diungkapkan Malinowski dalam Koentjaraningrat (1987) bahwa segala aktivitas kebudayaan bertujuan untuk memuaskan kebutuhan naluri manusia yang berkaitan dengan kehidupannya. Dalam sebuah peristiwa budaya dalam masyarakat adat Jawa Barat tentu saja selalu hubungannya dengan ritual, hiburan, maupun pertunjukan. Demikian halnya yang dilakukan oleh Masyarakat Adat 
Paseban Cigugur Kabupaten Kuningan.

Masyarakat adat Paseban merupakan salah satu dari beberapa kominitas masyarakat adat di Jawa Barat yang konsisten melakukan aktivitas tersebut. Sudah sejak lama komunitas ini membuat sebuah aktivitas seni budaya yang dinamakan Seren Taun yang dilaksanakan satu tahun satu kali. Dalam event menghadirkan berbagai unsur masyarakat, dari aparat pemerintah daerah, pemangku agama, seniman, petani, pedagang, semua kalangan masyarakat dapat hadir dan menikmati sajian apa pun yang disediakan. Berbagai bentuk kesenian dari seni tari, kecapi suling, wayang golek, rengkong, angklung buncis, gondang, ngalisung, dan sebagainya dapat dinikmati.

Dari keberagaman seni yang disajikan dalam waktu satu minggu tersebut ada satu bentuk seni yang luput dari perhatian yaitu seni membatik. Batik dan peralatannya hanya dipamerkan saja di salah satu sudut tempat berlangsungnya kegiatan Seren Taun tanpa ada sentuhan lain yang mungkin dapat menarik perhatian masyarakat. Padahal, potensi batik dewasa ini dapat menjadi komoditi ekonomi yang menjanjikan. Dari hasil penelitian di dalam Masyarakat Adat Paseban ini terdapat berbagai macam motif batik yang pernah dibuat oleh para leluhurnya. Motif-motif yang ada memiliki kekhasan yang tentunya berbeda dengan motif batik daerah-daerah lain. Dalam beberapa tahun ini Rama Djati sesepuh dari komunitas tersebut sedang berupaya menggali dan mengembangkan batik Cigugur untuk diperkenalkan dan disebarluaskan kepada masyarakat umum. Dari hasil penggalian kembali yang sudah dilakukan sejak tahun 2005 oleh Rama Djati dan putra putrinya telah ditemukan sepuluh motif batik. Namun dalam kesempatan Seren Taun itu, batik belum disentuh serius untuk dipublikasikan. Hal inilah yang menjadi permasalahan di mana batik sebagai salah satu aset yang dimiliki oleh masyarakat Adat Paseban belum banyak diketahui masyarakat umum. Padahal motif-motif batik yang dimiliki sangat menarik dan unik. Berdasarkan fenomena tersebut permasalah yang diangkat adalah: (1) Bagaimana membuat model pemberdayaan masyarakat berbasis aktivitas seni budaya lokal; (2) Bagaimana meningkatkan perekonomian masyarakat; dan (3) Bagaimana meningkatkan sadar budaya dan apresiasi masyarakat terhadap seni tradisional masyarakat;serta (4) Bagaimana meningkatkan kesadaran pentingnya jalinan harmoni sosial melalui aktivitas seni budaya lokal.

\section{PEMBAHASAN}

Berdasarkan permasalahan tersebut penulis mencoba memberdayakan potensi ini dengan cara membuat kemasan tari batik yang digarap menjadi sebuah bentuk seni pertunjukan yang kemudian diajarkan kepada masyarakat luas melalui sekolah maupun sanggar-sanggar tari yang ada di Kabupaten Kuningan. Langkah ini diharapkan akan meningkatkan aset perekonomian dari masyarakat Paseban itu sendiri dan juga dapat mempererat hubungan sosial antara masyarakat adat Paseban dengan masyarakat umum khususnya di Kabupaten Kuningan.

Tujuan jangka panjang penelitian ini adalah: (1) Mengharmoniskan interaksisosial masyarakat adat Paseban dengan masyarakat sekelilingnya; (2) Meningkatkan perekonomian masyarakat Paseban 
dan masyarakat sekelilingnya yang berbasis seni budaya; (3) Menumbuhkan apresiasi generasi muda terhadap budayanya; serta (4) Meningkatkan perekonomian masyarakat berbasis aktivitas seni budaya lokal. Sementara tujuan jangka pendeknya adalah: (1) Menemukan model pemberdayaan masyarakat berbasis aktivitas seni budaya lokal; (2) Bagaimana meningkatkan perekonomian masyarakat; dan (3) Bagaimana meningkatkan sadar budaya dan apresiasi masyarakat terhadap seni tradisional masyarakat;serta (4) Bagaimana meningkatkan kesadaran pentingnya jalinan harmoni sosial melalui aktivitas seni budaya lokal.

Tujuan-tujuan yang dirumuskan tersebut sangat penting dilaksanakan dalam penelitian ini terutama dalam memberdayakan masyarakat dan segala potensinya dalam aktivitas seni budaya untuk mengokohkan integrasi bangsa dana presiasi terhadap seni budaya lokal. Hal ini sangat diperlukan dalam upaya mendukung strategi nasional Indonesia dalam meningkatkan kesejahteraan masyarakat dan pengentasan kemiskinan, serta upaya pelestarian dan pengembangan seni budaya.

Sampai saat ini, sebagian orang berpandangan, bahwa pelestarian dan pengembangan seni pertunjukan diserahkan kepada dunia pendidikan, sehingga masyarakat sebagai pemilik budayanya kurang dapat mengapresiasi, bahkan menjadi asing akan keseniannya. Padahal pada masa lalu masyarakat menjadi sponsor utama terhadap kehidupan kesenian tradisional, sehingga menyadari betul bahwa fungsi seni yang utama adalah untuk menjalin persaudaraan. Oleh karenyanya kini diperlukan sebuah strategi untuk memfungsikan kembali potensi seni bu- daya lokal sebagai ajang silaturahim antar anggauta masyarakat, hingga mewujudkan harmoni sosial.

Jika gagasan program ini bisa tercapai, maka akan besar kontribusinya terhadap kehidupan masyarakat yang kini bermasalah dengan interaksi sosial. Oleh karena itu, penelitian ini sangat penting dilakukan karena diharapkan akan membawa manfaat bagi masyarakat. Adapun bagi seniman yang bergelut dengan kehidupan seni di tempatnya dapat meningkatkan kreativitas seninya. Hal ini sebagai upaya bersama dalam mengkemas seni budaya dan berdampak pada jalinan sosial yang harmonis. Dengan demikian diharapkan hasil penelitian ini dapat menyentuh kesadaran masyarakat akan potensi seni budaya yang dapat diberdayakan untuk meningkatkan pendapatan mereka.

Pemberdayaan masyarakat (people empowerment) dikenal sebagai power trasfer kepada mereka yang tidak berdaya agar mampu secara mandiri membuat keputusan atau tindakan yang terbaik untuk kehidupan ke depan. Aspek-aspek pemberdayaan masyarakat dilihat dari segi hak rakyat menyangkut tiga dimensi yaitu politik, ekonomi, dan sosial. Dari dimensi politik, dimaknai sebagai akses masyarakat dalam proses pengambilan keputusan yang melibatkan publik. Pemberdayaan masyarakat dari dimensi ekonomi dimaknai sebagai akses masyarakat atas sumber-sumber pendapatan untuk dapat hidup layak. Sementara dari segi sosial, dimaknai dengan akses masyarakat terhadap pelayanan sosial (Muflich, tth).

Metode penelitian yang digunakan adalah metode eksperimen. Melalui metode ini penulis melakukan kegiatan percobaan untuk melihat suatu hasil. Tu- 
juan dari eksperimen ini bukan untuk mendeskripsikan data melainkan pada penemuan faktor-faktor penyebab dan akibat (Surachmad, 1980: 149). Dalam hubungannya dengan kegiatan seni khususnya tari, metode eksperimen ini dituangkan dengan percobaan-percobaan pelalui eksplorasi khususnya eksplorasi gerak dari objek yang diangkat untuk mewujudkan susunan tari atau koreografi.

Dalam menunjang metode eksperimen itu penulis juga melakukan observasi, mewawancarai narasumber, dan merekam berbagai aktivitas seni budaya secara visual maupun audio visual. Selanjutnya dilakukan observasi untuk mendapatkan data aktivitas seni budaya yang dilakukan dalam masyarakat Adat Paseban. Wawancara dilakukan secara terstruktur maupun tidak terstruktur kepada pengelola sentra budaya, seniman sebagai pelaku kegiatan seni budaya, masyarakat pendukung, pejabat terkait di wilayah sentra-sentra seni wisata, dan masyarakat sekitarnya yang berperan mendukung seni wisata. Kegiatan-kegiatan di lapangan selalu dibarengi dengan perekaman oleh kamera photo dan video.

\section{Kesenian dalam Masyarakat Adat Paseban}

Masyarakat Adat Paseban Cigugur Kuningan merupakan salah satu kelompok masyarakat adat yang mewarisi tradisi dari keturunan Kyai Madrais. Kyai Madrais adalah seorang keturunan Cirebon yang menyebarkan ajarannya yang disebut agama Jawa Sunda. Doktrin yang diterpkan kepada para muridnya adalah untuk menghargai sesama umat manusia tentang tata cara dan ciri kebangsaan sendiri berdasarkan tata tertib yang berlaku dalam ajaran agama Jawa Sunda.
Tidak dibenarkan apabila meniru dan menggunakan cara budaya lain (Subiantoro, 2004: 27). Banyak tradisi ritual yang dilakukan oleh komunitas masyarakat adat ini, dalam ritual yang dilakukan terdapat unsur seni yang menonjol.

Seni dalam komunitas Masyarakat adat Paseban menjadi salah satu unsur yang diusung untuk tetap dilestarikan, karena dianggap memiliki nilai-nilai lokal genius yang tidak ternilai. Beberapa bentuk kesenian yang masih terpelihara di antaranya adalah Tembang Sunda Cianjuran, Gamelan Monggang Paseban, tari-tarian Paseban, dan batik. Dari semua jenis kesenian tersebut terdapat kelompok-kelompok khusus, demikian halnya dengan kelompok pengrajin batik. Semua kelompok seni tersebut tergabung dalam sanggar seni "Purwawirahma" yang anggota senimannya diperkirakan berjumlah lima puluh orang. Grup Tembang Sunda Cianjuran merupakan grup yang cukup intensif dalam melakukan latihan, namun demikian belum sampai menghasilkan seniman-seniman yang handal. Hal ini terbukti dengan masih menggunakan seniman atau penembang luar dari Paseban jika ada pertunjukan dalam skala besar. Seperti dalam rangka upacara Seren Taun yang diselenggarakan satu tahun sekali. Grup ini masih sering menggunakan penembang dari Bandung yaitu Mamah Dasimah. Sementara penembang yang lokal nampaknya belum bisa dimunculkan dalam Seren Taun besar karena masih perlu banyak latihan.

Selain Tembang Sunda Cianjuran terdapat kelompok seni tari. Keberadaan kelompok tari dapat dikatakan lebih maju bila dibandingkan dengan kelompok lainnya. Anggotanya pun cenderung cukup banyak, terutama kaum perempuan. Salah satu tarian khusus yang sangat terkenal 
di Cigugur adalah Tari Buyung, yaitu tarian yang menggunakan properti buyung. Jumlah penari Buyung mencapai ratusan, namun ditampilkan silih berganti sesuai dengan kebutuhan. Banyak penari yang mengundurkan diri ketika mereka sudah menikah. Namun demikian selalu datang lagi pengganti dari generasi yang baru. Usia para penari Buyung antara 13-24 tahun. Pada umumnya mereka usia sekolah SMP dan SMA. Kadang ada pula ibu rumah tangga yang masih usia muda. Biasanya sekali pentas Tari Buyung dalam ritual Seren Taun bisa mencapai enam puluh penari. Tarian ini menjadi tarian khas yang sering kali menjadi harapan dan cita-cita anak-anak kecil yang masih diusia SD. Dari hasil wawancara terhadap beberapa anak kecil diketahui bahwa mereka memiliki cita-cita menjadi seorang penari yaitu penari Tari Buyung. Alasan pasti mengapa mereka bercita-cita ingin menjadi penari karena Tari Buyung menjadi tarian khas yang selalu disajikan dalam upacara adat Seren Taun yang digelar pada setiap satu tahun satu kali. Sajian ini selalu ditonton masyarakat luas. Selain itu, terdapat pula jenis tari lain yaitu Tari Badaya Gebang, namun tarian ini belum populer karena hanya digelar dalam Seren Taun tertentu. Kendati bentuk-bentuk kesenian yang terus dilestarikan hanya beberapa bentuk, tetapi ketika pelaksanaan Seren Taun beberapa kesenian rakyat dihadirkan di sana seperti Rengkong, Angklung Buncis, Wayang Golek, dan sebagainya.

Fasilitas kegiatan berkesenian para seniman khususnya masyarakat Adat Paseban cukup representasif karena ditunjang oleh tempat latihan yang memadai. Beberapa tempat pertunjukan di dalam maupun di luar ruangan sangat memungkinkan. Ada panggung terbuka dan ada panggung tertutup. Mereka juga memiliki tempat yang bagus tempat pelaksanaan kegiatan budayaan mereka yaitu Gedung Paseban Tri Panca Tunggal. Di dalamnya terdapat beberapa ruangan yang spesifik dengan fungsinya masing-masing. Di tengah ruangan terdapat berbagai peninggalan $l e-$ luhur mereka serti ada kursi Gading Gilang Kencana yang sangat unik sebagai tempat duduk para penguasa mereka. Dilengkapi pula dengan berbagai bentuk kursi yang merunut pada bentuk-bentuk lama. Di kiri-kanan terdapat beberapa peninggalan benda kuno, seperti tombak, ukiranukiran yang unik sebagai peninggalan mereka secara turun temurun.

Ruangan utama dalam gedung itu disebut dengan ruang jinem. Keberadaannya sangat representatif untuk melaksanakan kegiaran-kegiatan budaya. Demikian pula dengan kegiatan kesenian. Di tempat tersebut dapat malakukan kegiatan berkesenian. Untuk latihan tari dapat dilakukan di tengah ruangan tengah. Sementara untuk latihan Gamelan Monggang hanya bisa dilakukan di tempat tersebut yaitu sebelah kanan ruangan. Gamelan tersebut merupakan gamelan tua yang dikeramatkan. Penabuhnya tidak sembarangan orang bahkan dalam cara menabuhnya pun terdapat aturan tertentu. Salah satunya tidak boleh menabuh dengan cara keras tetapi harus ditabuh dan diperlakukan dengan lembut.

Di sekeliling ruangan terdapat hiasanhiasan benda seni yang cukup unik ada berbagai bentuk mengenai ukiran yang terbuat dari kayu maupun benda-benda sebagai senjata, seperti tombak, gada, payung kebesaran, bendera, lambang dan simbol dari komunitas masyarakat tersebut, dan lain-lain. Juga terdapat beberapa benda seni lain yang fungsional seperti ke- 
capi. Benda-benda tersebut disimpan dan ditata sangat artistik sehingga memanjakan mata yang memandangnya. Salah satu benda tersimpan pula di sudut ruangan. Benda tersebut awalnya berfungsi sebagai alat tumbuk padi yang dinamakan lisung tetapi kini telah dibuat menjadi benda artistik yang difungsikan sebagai benda seni untuk kebutuhan apresiasi.

\section{Pemberdayaan Masyarakat Melalui Karya Tari}

Melihat berbagai fenomena yang terjadi dalam kehidupan berbudaya Masyarakat Adat Paseban Cigugur, terdapat sebuah peristiwa penting yang harus diangkat untuk dijadikan sebuah konsep dan model dari seni lokal untuk menciptakan interaksi sosial yang harmoni. Kegiatan membatik pada masyarakat ini menarik perhatian tim penulis untuk diangkat sebagai sumber penggarapan karya yang nantinya akan disebarkan pada masyarakat luas. Berbagai motif batik mulai dikembangkan oleh pengrajin batik masyarakat Paseban. Sejak tahun 1992 masyarakat adat ini menemukan motif-motif batik gaya Cigugur yang sudah dibuat oleh para nenek moyangnya yang tersimpan sebagai benda peninggalan mereka. Kemudian Rama Djati mencoba mengungkap lebih teliti dan menuangkan motif-motif yang ditemukan ke dalam karya yang riil. Berbagai motif telah dicoba diangkat sehingga terwujudlah sepuluh (10) motif batik dari hasil revitalisasi dan rekonstruksi para ahli batik di Paseban, terutama Rama Djati itu sendiri. Adapun nama motif-motif batik yang ditemukan adalah sebagai berikut. (1) Mayang Segara, (2) Oyod Mingmang, (3) Sekar Galuh, (4) Rereng Kujang, (5) Kadatuan, (6) Gagang Senggang, (7) Geger Sunten, (8) Sekar Kancana,
(9) Adu Manis, dan (10) Rereng Powahaci. Keragaman batik tersebut belum dikenal oleh masyarakat banyak.

Sejak tahu 2005 batik Cigugur mulai diujikan dan diproduksi namun hanya kalangan tertentu yang mengetahuinya. Maka kesempatan ini sangat baik bila ditindaklanjuti dengan mengangkat batik sebagai sebuah strategi untuk membuat model sebuah tarian yang nantinya diharapkan terjalinnya interaksi sosial diantara masyarakat Paseban Cigugur dengan masyarakat Kuningan pada umumnya. Strategi pemberdayaan batik ini adalah dengan membuat sebuah tarian yaitu tari Batik agar nantinya batik Paseban dapat dikenal oleh masyarakat luas.

Proses pemberdayaan seni yang mengangkat objek batik ini dilakukan dengan menggunakan metode eksperimen. Eksperimen dalam garapan tari adalah dilakukannya eksplorasi yang dilanjutkan dengan penerapan dan pelatihan. Namun demikian observasi terhadap bagaimana proses pembuatan batik tersebut tetap dilakukan sebagai tahap awal penelitian. Observasi ini dilakukan wawancara dengan Rama Djati dan putra-putrinya yang terjun langsung menjadi pengrajin batik, serta kepada para pegawainya. Tahap selanjutnya penulis membuat konsep koreografi dan musiknya. Setelah konsep tarian matang, dilakukan eksplorasi gerak bersama pelatih.Adapun gerak yang dieksplor dan dikembangkan di antaranya gerak, mincid, tindak tilu, trisi, bokor sinongo, keupat, dan gerakan-gerakan keseharian dari tatacara membatik. Dari proses eksplorasi tersebut gerak dipilih dan disusun hingga terwujud menjadi sebuah koreografi atau tarian. Dalam tarian tersebut digambarkan proses pembuatan batik dari mulai pemilihan bahan, mo- 
tif, serta pembatikkannya, hingga menjadi alat penutup tubuh atau menjadi baju yang kemudian dipamerkan kepada para penikmatnya.

Tarian yang telah disusun tersebut diberi judul "Tari Batik Sekar Galuh". Nama Tarian ini menggambarkan sebuah bunga yang terus mewangi sebagai simbol tradisi yang hidup dan menghidupi dengan keharumannya. Tarian ini diiringi oleh musik gamelan monggang gamelan buhun yang dimiliki komunitas adat masyarakat Paseban secara turun temurun. Adapun iringan tariannya menggunakan lagu Gunungsari yang ditata kembali sesuai dengan kebutuhan gerak tari.

Tari Batik Sekar Galuh kemudian dipertunjukkan dalam acara upacara tahunan Seren Taun yang digelar tahun 2012. Tarian ini kemudian diresmikan oleh Rama Dja- ti sebagai tarian baru sebagai tarian khas seperti Tari Buyung. Tarian yang dikemas ini selanjutnya diharapkan akan dijadikan materi pertunjukan sebagai ciri khas tarian daerah Cigugur Kuningan. Dalam proses penggarapan tarian ini sementara dilatihkan kepada lima orang penari. Di antaranya yaitu Wiwit, Citra, Tresna, Nani, dan Wina. Pengarapan koreografi, musik maupun kostum memberdayakan apa pun yang ada dalam komunitas tersebut. Kostum yang digunakan oleh para penari adalah apok, kain batik, ikat pinggang, serta bersanggul cepol yang diberi hiasan rambut. Properti yang digunakan adalah kain batik yang berbeda corak, motif, dan warna. Kain batik yang digunakan semuanya adalah jenis kain yang telah dibuat oleh para perajin batik pada masyarakat Adat Paseban.

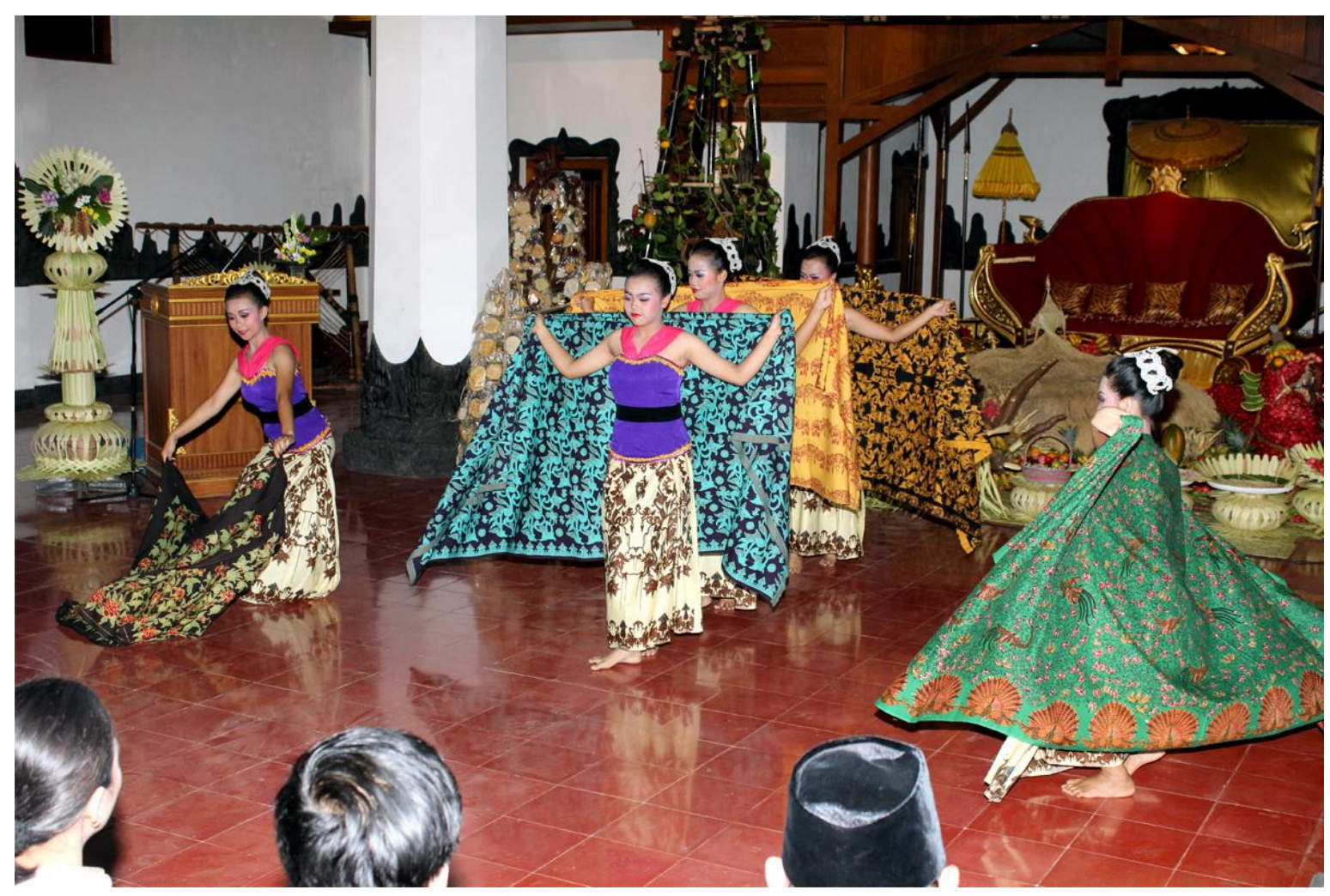

Pertunjukan Tari Batik Sekar Galuh Sebuah Kemasan Garapan Tari berbasis Aktivitas Budaya Lokal 6 November 2012 
Pemberdayaan masyarakat Adat Paseban Cigugur Kuningan yang telah dilakukan oleh penulis membuat konsep seni lokal untuk menciptakan interaksi sosial yang harmonis di antara masyarakat Cigugur dengan masyarakat secara umum. Konsep seni tersebut dibuat dalam bentuk garapan tari yang nantinya kemudian disosialisasikan kepada masyarakat. Dengan karya tari tersebut diharapkan dapat mempererat tali persaudaraan antar warga. Ketika tarian kreasi ini digelar banyak masyarakat umum di luar masyarakat Paseban yang menonton dan berniat ingin mempelajari tarian tersebut.

Dalam garapan ini memunculkan adanya rekayasa sosial yang dapat menjadi dan menghasilkan dampak sosial (social impact) dan dampak ekonomi (economic impact). Social impact yang ada adalah terdapatnya edukasi dan attitude. Juga dampak sosialnya dapat menghidupi seniman dari keseniannya. Mereka para seniman yang terlibat dapat hidup kembali karena garapan kreasi atau kemasan yang dibuat mengikuti perkembangan zaman. Tarian ini dikemas dengan model dan selera kekinian sehingga kemungkinan besar dapat disukai oleh para generasi muda. Sementara dampak ekonomi dari kegiatan ini adalah terhadap perkembangan pariwisata. Munculnya karya baru yang mungkin dapat dijual sebagai kebutuhan pariwisata. Ada nilai jual yang meningkatkan pendapatan bagi para senimannya. Setelah dikukuhkan oleh sesepuh sebagai tarian khas Cigugur selain tari Buyung, yang akan dipergelarkan dalam setiap pelaksanaan Upacara adat masyarakat Adat Paseban Cigugur yaitu dalam Seren Taun yang digelar satu tahun sekali.

Dari kegiatan penelitian ini ada indikator peningkatan terhadap sumber daya manusia. Seperti kreator dari kelompok "Purwawirahma" ini yaitu Djuwita Djati yang pada saat penelitian dijadikan rekan untuk bereksplorasi menganggap penelitian ini penting sehingga dapat meningkatkan kemampuan dirinya dalam mengkemas sebuah tarian yang dapat memiliki nilai jual. Demikian halnya para penari yang dilatihkan mendapat peningkatan kemampuan menari yang lebih baik. Adanya penelitian ini meningkatkan industri kreatif dari para pelakunya. Karyakarya yang sudah ada dan sudah lama hanya itu-itu saja kini ditambah dengan tari Batik yang dapat lebih mempopulerkan karya barunya juga mempopulerkan batik yang sedang dikembangkan oleh masyarakat adat Paseban Cigugur.

Dengan adanya sentuhan dari tim penulis dalam melakukan kegiatan ini, telah tampak ada semangat baru untuk berkreasi baik dari pimpinan sanggar tersebut maupun para penarinya. Semangat ini akan meningkatkan produktivitas kreasi-kreasi baru yang ingin dikembangkan oleh mereka. Dengan semangat baru itu kemungkinan besar akan adanya peningkatan ekonomi karena dapat meningkatnya frekuensi pemanggungan mereka. Bahkan kemungkinan besar pada tahun mendatang merekalah yang akan melatihkan tarian ini kepada masyarakat baik itu sanggar-sanggar tari maupun ke sekolah-sekolah tingkat menengah pertama dan atas.

\section{PENUTUP}

Dari hasil eksperimen yang dilakukan peneliti, maka terwujudlah sebuah tarian berjudul Tari Batik Sekar Galuh yang kemudian dijadikan model pengkemasan seni 
untuk diterapkan dan disosialisasikan kepada masyarakat melalui sanggar-sanggar tari maupun melalui pendidikan formal di beberapa sekolah di daerah Kuningan. Hal ini dilakukan sebagai upaya pemberdayaan seni berbasis aktivitas budaya lokal. Dengan cara seperti itu, diharapkan seni tari yang sumbernya diangkat dari kekayaan seni daerah itu sendiri dapat disukai oleh masyarakat banyak. Akan juga terjalin hubungan yang erat secara tidak langsung antara masyarakat Paseban dengan masyarakat umum di Kuningan. Tarian Batik yang dibuat berdasarkan pada gerak-gerak tari yang hidup di Jawa Barat.

Berdasarkan tujuan pertama yang ingin dicapai dalam penelitian ini adalah menemukan model pemberdayaan masyarakat melalui aktivitas seni budaya maka dihasilkan kemasan tarian yang sumber dari kehidupan masyarakat Paseban khususnya dari aktivitas membatik. Aktivitas membatik diangkat sebagai sumber utama hal ini berkaitan dengan tujuan berikutnya yaitu untuk meningkatkan perekonomian masyarakat Paseban dan masyarakat sekelilingnya yang berbasis seni budaya. Peningkatan perekonomian ini adalah ketika masyarakat luas telah mengenal batik yang dimiliki masyarakat Paseban maka Batik Paseban akan menjadi bahan komoditi yang dapat dijual pada masyarakat luas. Selanjutnya masyarakat juga diberi apresiasi tentang kekayaan batik yang dimiliki masyarakat Paseban sebagai warisan budaya nenek moyangnya. Dengan diperkenalkan kepada masyarakat melalui tarian hal ini dapat menumbuhkan apresiasi generasi muda terhadap potensi budaya daerahnya, serta meningkatkan kesadaran masyarakat akan pentingnya jalinan harmoni sosial melalui aktivitas seni budaya lokal.

Model empowering (pemberdayaan) masyarakat adat ini sebagai rekayasa sosial yang telah dilakukan dengan dengan mengandalkan konsep seni lokal yang dibuat adalah untuk menciptakan interaksi sosial yang harmonis. Penulis yakin, bahwa penelitian ini dapat memberikan kontribusi kepada masyarakat untuk membantu mengurangi benang kusut yang menyebkan disharmoni sosial antar warga Masyarakat Adat Paseban Cigugur Kuningan dengan masyarakat sekitarnya melalui aktivitas seni budaya menuju kehidupan masyarakat yang harmonis. Dari aktivitas seni tersebut secara riil dapat dilihat adanya nilai-nilai kreativitas, nilai sosial, dan juga nilai ekonomi, maka pemberdayaan masyarakat semacam itu akan dirasakan manfaatnya. Dalam arti lain bahwa dengan kegiatan pengkemasan seni ini dapat meningkatkan kreativitas seni dalam masyarakat. Selain itu, kegiatan ini menjadi ajang promosi yang dapat meningkatkan perekonomian masyarakat penyangganya.

Hal ini terbukti dengan digelarnya karya tarian ini masyarakat Paseban maupun masyarakat umum berbaur melakukan apresiasi terhadap kesenian tradisi yang telah dikemas dalam nuansa kekinian. Kemudian strategi keberlanjutan adalah dengan menyebarluaskan tarian yang telah digarap kepada masyarakat umum, terutama kepada sekolah-sekolah dan sanggar-sanggar tari di daerah Kuningan. Masyarakat diyakinkan akan kembali merajut ikatan sosial yang memudar melalui perantara nilai-nilai aktivitas seni budaya. Dan kini, keberadaan itu terlihat semakin menunjukkan keharmonisannya. 


\section{DAFTAR PUSTAKA}

Ayip Muflich.

Tth. "Masalah dan Kebijakan Pemberdayaan Masyarakat dalam Mendukung Ketahanan Pangan" http://pse.litbang.deptan.go.id/ ind/pdffiles/Pros_AYIP_06.pdf.

Basuki Nursananingrat.

1964. "Purwawisada Agama Sunda" (Manuskrip). Bandung.

Didin Nurul Rosidin.

2000. Kebatinan, Islam, and The State: The Dissolution of Madrais in 1964. Tesis. Leiden: Faculties of Art and Theology Leiden University.

Ign. Herry Subiantoro.

2002 Upacara Seren Taun Sebuah Ritual Keagamaan di Cigugur Kuningan Jawa Barat. Tesis. Yogyakarta: Program Pascasarjana Universitas Gadjah Mada.

Ira Indrawarhana.

2009. Komunikasi Budaya Masyarakat Berbeda Keyakinan sebagai Peserta Upacara Adat Seren Taun di Cigugur Kuningan Jawa Barat. Tesis. Bandung: Program Pascasarjana Ilmu Komunikasi Universitas Padjadjaran.

Koentjaraningrat.

1958. Metode-metode Antropologi dalam Penyelidikan-Penyelidikan $\quad M a-$ syarakat dan Kebudayaan di Indonesia. (Sebuah Ichtisar) Djakarta: Universitas Indonesia.
1979. Gedung Paseban Tri Panca Tunggal Cigugur Kuningan. Kuningan: Yayasan Tri Mulya.

Soerjono Soekanto.

1986. Talcot Parson: Fungsionalisme Imperatif. Jakarta: Rajawali.

Stake.

1995. R. E., The Art of Case Study Research. California: Sage Publications, Inc.

Tedja Buana.

Tth. Agama Jawa Sunda (Madraisme). Kuningan: Yayasan Tri Mulya.

Wawan Hernawan.

2005. Komunikasi Antarumat Berbeda Agama: Studi Kasus Sikap Sosial dalam Keragaman Beragama di Kecamatan Cigugur Kabupaten Kuningan Jawa Barat. Disertasi. Bandung: Program Pascasarjana Ilmu Komunikasi Universitas Padjadjaran.

Winarno Surakhmad.

1980. Pengantar Penelitian Ilmiah: Dasar, Metode, Teknik, Bandung: Tarsito. 